\title{
APPLICATION OF CONTENT ANALYSIS IN PEDAGOGICAL RESEARCH AND PRACTICE
}

\section{Abstract}

Content analysis is one of the oldest research and most used techniques in social research and pedagogy, with invaluable significance and contribution to the development of educational science and pedagogical practice. At the beginning of its use, this technique had mainly a quantitative character, and later it was developed as a qualitative research technique that aims to reveal the hidden, symbolic meanings of the content in a certain context.

In its contemporary meaning and form, content analysis has great potential in studying the pedagogical phenomena, but also for application in the daily educational work in school and extracurricular activities.

In the particular research, the content analysis is applied in the instruction of the teaching subject Macedonian language in the initial two educational cycles of primary education. The subject of analysis is the readings recommended with the subject curriculum, which includes readings written by domestic and foreign authors with different genres and genders.

The results contain quantitative indicators about the presence of certain types of reading works and qualitative analysis in reference to the reading content, educational and emotional potentials, and ethical impact on students.

Keywords: CONTENT ANALYSIS, RESEARCH TECHNIQUE, READING WORKS, PEDAGOGY

\section{Introduction}

Content analysis is one of the oldest research techniques. Its use in qualitative research differs from the classical one used in quantitative research. The classical analysis aims to present the content of a verbal, non-quantitative document using quantitative indicators and drawing systematic conclusions. Therefore, content analysis of this kind can be included in the group of objective, quantitative techniques.

In later research, content analysis is applied as a typical qualitative technique which, in addition to the obvious, manifest characteristics of the documents, aims to reveal the hidden, symbolic meanings of the text, the motives of the author, and the context in which a work has been created. Contemporary 
content analysis does not only count occurrences of the words and phrases in particular text but aims to go deeper and to understand their meaning.

Apart from the scientific-educational research, content analysis can be used in the teaching process and has the potential to improve the work of teachers, pedagogues, educators.

\section{Content analysis as a research technique}

Content analysis was primarily developed as a technique for analysis of communication, exploring the content of political documents and, later, evaluating journalistic articles. Berelson defines content analysis as a research technique with the task to provide "an objective, systematic, and quantitative description of the apparent content of communication." (Berelson, 1995). The classics of content analysis (Lasswell, Lazarsfeld, Berelson) believed that if we insist on its quantification we would make this technique more objective. In the contemporary definitions of content analysis, it is not only the quantitative nature that is insisted upon but its focus shifts from the obvious contents of documents to the more hidden and symbolic meanings. In addition to the visible meaning, the text usually has a latent, figurative meaning. In order to be able to discover it, it is necessary to see the relation between the text and the context in which the text was created. For example, Kripendorf (1981) gives the following definition: "Content analysis is a research technique for deriving repetitive and reliable conclusions from content and its context" (according to Gredelj, 1986)

Therefore, content analysis can be understood as a qualitative technique that studies the hidden, symbolic meanings of messages based on the context in which they originated. Instead of the documents themselves as a subject of analysis, in this case, we also try to find out data about the person who created them, about his characteristics, goals, and motives in order for those messages to be written. Some methodologists call this technique contextual analysis.

The content analysis has great potential for application in the research of social and educational problems both as an independent and as an auxiliary research technique. It can be used in comparative research of the educational goals in various systems, in analysing of curricula, in the evaluation of the textbooks from different aspects, in assessing the concepts and contents of learning, in exploring the attitudes of the relevant subjects on teaching, communication, student behaviour, in analyzing historiographical documents significant for the development of education, in making portraits of eminent persons from the pedagogical history, in the evaluation of the contents of the readings, discovering their ideological and political background, etc. 


\section{Application of content analysis in educational research - methodological issues}

Content analysis is one of the most commonly used techniques in pedagogical research. Almost in every educational research, we can use content analysis to obtain relevant data through analysis of diaries, notes, spreadsheets, written preparation, pedagogical and other documentation.

The first attempts to formalize the content analysis, through insisting that it should be used according to previously established requirements, were made in the field of communication. The basis of every human communication is the content that we can define as a set of messages expressed in different ways and with different symbols: words, formulas, music, graphics, art, three-dimensional, etc. In order to be able to study all the components of human communication, and especially to understand the message that the "sender" sends to the "recipient", it was necessary to find a way to analyze the content of such communication. When the content analysis is turned into a research technique, certain methodological requirements are established.

The main goal of any content analysis as a research technique is to come to the objective data and facts relevant to the subject of study. These facts are contained in various sources. Actually, these sources are documents in which facts are noted, expressed, or preserved in different ways. The documents (sources) of facts can be: written sources, photographs, drawings, pictures, movies, radio recordings and other audio sources, television and video recordings, computer-aided recordings, three-dimensional means (space, buildings, equipment, furniture, means of work and entertainment). The symbols that are used to notify the facts in those sources can be different (from plain written, through mathematical, musical, computer, artistic, to rhythmic, facial expression, manner of behaviour, etc.).

In the sphere of education and pedagogy, we use specific categories of documents for content analyses in the process of educational research, such as the following: official documentation, laws, regulations, statutes, and acts in the field of education, school documentation, documentation of extracurricular institutions relevant to the education of children and adults, personal documentation of professionals relevant to the upbringing of children, student portfolio, pedagogical works, photographs of prominent pedagogues, video recordings of pedagogical practice, three-dimensional means of classrooms and entertainment, instruments that are used in the pedagogical research and other various documents of pedagogical theory and practice.

The mentioned documentation can refer to the past, to a certain period, certain types of institutions or individuals, and it can also refer to the present. Depending on the type of source, the facts in that documentation can be written in different ways and have a quantitative or qualitative character.

The sources of facts in the processing documentation can be primary when they occur directly in the process of upbringing and education, for example, in schools or other educational institutions. These are original documents for the educational process and for the subjects that participated in it, for the conditions in which the upbringing took place, etc. Pedagogical research that uses primary sources of facts is more objec- 
tive and whenever it is possible we should strive to obtain primary data. Still, there are situations when there is no possibility to access primary data sources and in that case, secondary, tertiary, and other sources are used. We take secondary sources of facts from research that are already conducted, especially when it comes to phenomena that have been studied in the past or by researchers from other geographical regions.

The course of content analysis is similar to the general course of educational research, with certain specifics unique for this research technique.

When the researcher has chosen the subject of research, formulated the goal, tasks, and hypotheses and when the time period of the study has been determined, he/ she is faced with the task of determining which documents are relevant for the subject of study and where those sources of facts are located. First, the researcher should make a list of all available sources. Compiling such a list of sources is not simple and easy. Sometimes it takes a very long time to search for some documents and sources. In this process, the researcher can consult: pedagogical bibliographies, library catalogues, archive materials, catalogues and collections from museums, digital databases, interviews, and informal conversations with individuals.

When the list of available sources is compiled, it is necessary to make a critical assessment of the value of the sources before proceeding to the analysis of the content of those sources. This means to determine whether the sources are original and authentic, whether they really arose in the process of educational activity, whether they refer to the selected period of time in accordance with the subject of research, who is the author of those documents, in what circumstances they were created. This is called external review or verification of the document. After this external verification of the document, we move on to internal verification, which means checking whether the data contained in a source are accurate, complete, objective, and impartial. The facts from one source are compared with the facts from other sources and it is determined whether they are the same or different.

During the research that uses the content analysis technique and relies on facts from a variety of sources, the researcher should categorize the sources. It is not enough to determine whether the sources are primary or secondary, but it is also necessary to determine whether they are significant, important, representative, complete and sufficient.

In order to be able to analyze the content of the selected sources, the researcher must clearly define the unit for content analysis. He must determine precisely what he is looking for in the selected sources, what is to be identified and noted as a fact in the process of analyzing the content of a source.

If there are several types of units for content analysis, the researcher must establish a criterion for their classification and sorting. It assumes that the categories are determined, according to a given criterion, in which all collected units will be classified.

Finally, before starting the realization of this research technique, the researcher must predict how the results obtained from the content analysis of the sources that were used, will be recorded. As there are different documents and sources, the recording of facts will be different. The different recording will also depend on whether it is a qualitative or quantitative set of data.

There are no standardized instruments for applying the content analysis technique, but there are some general methodological requirements and rich research expe- 
riences that can be of great benefit to the researcher. For each study, the researcher must determine the instruments for recording the units of content analysis. It is important for recording to be clear, concise, complete, easy to sort and process the collected facts.

In the following text, we will list some possible ways and tools for recording the facts as units of content analysis.

For analysis of the content of documents in written or otherwise noted form (art, film, or computer data), we can use various instruments: tables, reviews, data registers, checklists, etc. Qualitative facts (units of analysis) can be recorded on special cards, sheets, or leaflets. The size of the cards depends on the size and number of units of the content analysis. If we gather quantitative facts (units of analysis) we can use different tables, spreadsheets, and adequate checklists.

There are also Qualitative Analyses Data Softwares such as: MaxQDa, NVivo, Atlas.ti and similar programs for assistance in the process of data analyses.

If the critique and categorization of the sources are well done and if the criteria for the classification of the facts are determined by respecting the general methodological requirements, then we can successfully formulate conclusions and write a research report. The benefits of the application of content analysis are evidenced by a large number of researches in our country in which the technique of content analysis is applied as a basic or auxiliary technique for the study of pedagogical phenomena.

Further, we will present an example of the application of content analysis in specific pedagogical research, where the subject of analysis is the reading works in primary education.

\section{Content analysis of the readings within the subject of the Macedonian language in the first and second educational cycle of the nine-year primary education}

The content analysis was applied in the research "Use of literary works in the teaching of Macedonian language" in which a quantitative and qualitative analysis of the use of reading works in the subject Macedonian language in the first and second educational cycle of the nine-year primary education was performed (Janevska, 2021).

For the purpose of the research and in accordance with the defined goals, tasks, and research questions, a tool for content analysis was constructed in the form of a checklist with the relevant aspects of the research. 
Checklist for analysis of the reading works according to the program for the subject Macedonian language from second to sixth grade

\begin{tabular}{|c|c|c|}
\hline $\begin{array}{l}\text { Ordinal } \\
\text { number }\end{array}$ & $\begin{array}{l}\text { Reading work } \\
\text { Author of the reading work }\end{array}$ & Presence \\
\hline \multirow{4}{*}{1.} & & \\
\hline & Domestic author & \\
\hline & Foreign author & \\
\hline & Folk prose & \\
\hline \multirow{3}{*}{2.} & Literary form & \\
\hline & Poetry & \\
\hline & Prose & \\
\hline \multirow[t]{5}{*}{3.} & Prose works & \\
\hline & novel & \\
\hline & fairy tales & \\
\hline & fables & \\
\hline & stories & \\
\hline \multirow{3}{*}{4.} & Poetic works & \\
\hline & epic songs & \\
\hline & lyrical songs & \\
\hline \multicolumn{3}{|c|}{ Literary elements } \\
\hline \multirow[t]{6}{*}{5.} & Theme & \\
\hline & from childhood & \\
\hline & from family life & \\
\hline & realistic & \\
\hline & fantastic & \\
\hline & historical & \\
\hline \multirow[t]{4}{*}{6.} & Title & \\
\hline & one word & \\
\hline & syntagma & \\
\hline & the same with topic & \\
\hline \multirow[t]{8}{*}{7.} & Localization & \\
\hline & narrower & \\
\hline & wider & \\
\hline & close to us & \\
\hline & distant to us & \\
\hline & in the city & \\
\hline & in the village & \\
\hline & in nature & \\
\hline
\end{tabular}




\begin{tabular}{|c|c|c|}
\hline \multirow[t]{11}{*}{8.} & Fabula & \\
\hline & continuous & \\
\hline & discontinuous & \\
\hline & easily understood & \\
\hline & difficult to understand & \\
\hline & long & \\
\hline & short & \\
\hline & interesting & \\
\hline & boring & \\
\hline & slow (stretched) & \\
\hline & fast & \\
\hline \multirow[t]{3}{*}{9.} & Problem & \\
\hline & there is a problem & \\
\hline & there is no problem & \\
\hline \multirow[t]{5}{*}{10.} & Characters - main characters & \\
\hline & children & \\
\hline & adults & \\
\hline & positive character & \\
\hline & negative character & \\
\hline 11. & What are the ethical potentials of work? & $\begin{array}{l}\text { not present at all } \\
\text { slightly present } \\
\text { highly present }\end{array}$ \\
\hline 12. & $\begin{array}{l}\text { What are the emotional potentials for a } \\
\text { child's personal development? }\end{array}$ & $\begin{array}{lllll}1 & 2 & 3 & 4 & 5\end{array}$ \\
\hline 13. & $\begin{array}{l}\text { How much does the work stimulate } \\
\text { children's interest in reading? }\end{array}$ & $\begin{array}{l}\text { - not present at all } \\
\text { - slightly present } \\
\text { - highly present }\end{array}$ \\
\hline
\end{tabular}

\section{Results}

According to the data obtained from the analysis of the characteristics of the reading works from the first two educational cycles, it can be concluded that the number of domestic and foreign authors is almost equal. Out of a total of 55 reading works, 28 are written by a domestic author, 25 are by a foreign author. It provides opportunities for students to get acquainted with domestic and foreign literary works.

The relatively small representation of the poetic reading works in relation to the prose reading works is noticeable, 10 respectively 43. In the first two educational cycles of primary education, the novels are most represented, 25. They are most represented in the sixth grade, even 9 or $36 \%$ of the total sample of reading works. In the first four grades, the number of reading works in the form of novels is less than twice in relation to their representation in the fifth and sixth grades. This ratio has a logical trend because in these two grades cur- 
ricula of the teaching subject in the Macedonian language become more complicated. It is obvious that there is no regular continuous trend in the occurrences of lyrical songs at different levels.

The percentage of this type of poetry is the highest in relation to all other types of poetic works, and it has the same values in the second and sixth grades, represented by two collections of lyrical poems.

During the analysis of the literary elements in the reading works in relation to the topic, results were obtained according to which in general it can be concluded that most of the topics refer to the life of children (57.78\%) and family life $(17.78 \%)$, which can draw a conclusion that $3 / 4$ of the topics are from the immediate life and environment in which children live. The realistic topics are represented with a high percentage of $44.44 \%$. Fantastic topics are represented by $55.6 \%$, with the highest prevalence of $36 \%$ in the fifth grade, and the percentage of fantastic topics in the sixth grade drops to $16 \%$.

Most of the actions according to the analysis of the localization take place at more distant localizations, and slightly less than half of the reading works take place in the children's close environment. The differences in terms of the actions that take place in the city and in nature are not significant, $48.89 \%$, respectively $42.22 \%$.

The plot is continuous and easy to understand in all reading works, with the exception of two reading works in which the plot is more difficult to understand. It is usually long, which is understandable because the most common form of reading works is the novel. According to the assessment, all reading works are interesting to read, and 19 reading works, or $42.22 \%$ have fast actions. Thirty-six reading works, i.e. $80 \%$ of them are amenable to problem analysis.

During the analysis of the characters in the literary works, the balanced distribution of characters of different ages is noticeable, whereby, according to the researcher, most of the characters 43 or $95.56 \%$ are characterized as positive characters. This distribution is quite understandable if we take into account that young readers identify with positive characters.

By this, it can be concluded that reading works have educational potentials for a positive impact on students.

The emotional potentials of the reading works are evaluated by the researcher, in order to examine the possibility of their influence on the students' emotional development, as well as the emotional experience in general, which develops when reading certain reading works.

The rating scale is expressed numerically with scores from 1 to 5 , where 1 is the lowest grade and 5 is the highest grade. Grade 1 indicates that the reading of the text in the reading work does not arouse any feelings in the student, does not encourage empathy or identification with the main character. Grade 2 indicates a weak, insignificant impact of the content of the work on the emotions of the student. Grade 3 characterizes the content that through reading arouses certain emotions in students and encourages thinking about how the character will behave further. Grade 4 characterizes the content of the reading 
work which arouses more pronounced feelings and develops greater empathy for the character and his actions. Grade 5 characterizes the content that has the greatest emotional impact on students and they think by projecting the same situation from the novel.

\section{Table 1}

Analysis of the emotional potentials of the reading works in the first and second educational cycle

\begin{tabular}{|c|c|c|c|c|c|c|}
\hline \multirow{2}{*}{$\begin{array}{l}\text { Assess- } \\
\text { ment of the } \\
\text { emotional } \\
\text { value of the } \\
\text { reading }\end{array}$} & \multicolumn{5}{|l|}{ Grade } & \multirow[b]{2}{*}{ Total } \\
\hline & $\begin{array}{l}\text { second } \\
\text { grade }\end{array}$ & $\begin{array}{l}\text { third } \\
\text { grade }\end{array}$ & $\begin{array}{l}\text { fourth } \\
\text { grade }\end{array}$ & $\begin{array}{l}\text { fifth } \\
\text { grade }\end{array}$ & $\begin{array}{l}\text { sixth } \\
\text { grade }\end{array}$ & \\
\hline 1 & 0 & 0 & 0 & 0 & 0 & 0 \\
\hline 2 & 1 & 0 & 0 & 0 & 0 & 1 \\
\hline 3 & 1 & 2 & 1 & 0 & 4 & 8 \\
\hline 4 & 1 & 3 & 7 & 7 & 4 & 22 \\
\hline 5 & 3 & 4 & 3 & 7 & 7 & 24 \\
\hline Total & 6 & 9 & 11 & 14 & 15 & 55 \\
\hline Average & 4.00 & 4.22 & 4.18 & 4.50 & 4.20 & 4.22 \\
\hline
\end{tabular}

From the obtained data it can be seen that the reading works have very high emotional potentials because the lowest average grade is 4.00 and refers to the reading works for the second grade, and the highest grade is 4.50 and refers to fifth-grade textbooks. This means that literary works with high emotional potentials are selected for reading works. The average grade for the emotional potential of all reading materials from second to sixth grade is 4.22 , which is a high value on a scale of 1 to 5 .

Consistent with this result is the fact that in the analysis of the ethical values of the reading works, as many as 47 of them, or $85.45 \%$ are very amenable to ethical evaluation. Through these results, it can be concluded that reading works have educational potentials and have a positive effect on students.

In the process of evaluating the ethical aspects of the reading works, it was evaluated whether the reading work stimulates values for correct, good behaviour of students, points them how to distinguish good from bad actions, helps them to discover the positive qualities and good actions of the characters from the work, to identify with them and to apply them, and to criticize, reject and condemn the bad, the wrong, the inappropriate and the evil. The rating scale is expressed in attributive categories such as categories: "not present at all", "slightly present" and "highly present".

Attributive category "not present at all" means that reading the text does not provoke any feelings of students, does not encourage empathy and identi- 
fication with the main character of the novel. The word "slight present" means that the content by reading would provoke at least some correct actions in the students and would encourage them to think - how the character could behave further, with such qualities. The attribute "high present" means that the content has the greatest ethical impact on students, they think critically and take a stand by projecting the same situation from the text.

\section{Conclusion}

In its contemporary meaning and form, content analysis has great potential for application in the study of pedagogical phenomena, but also for application in the daily educational work in school and extracurricular activities. In a large number of educational research, it is used as a basic technique for collecting data, but it becomes even more pronounced when it is applied in combination with other research techniques such as scaling, interviewing, testing.

In the applied research, the content analysis was used as the primary technique for evaluating the reading works recommended in the subject of the Macedonian language in the first two educational cycles of primary education. The results show that reading works are written by domestic and foreign authors with different genres and genders. The works have a strong potential for emotional and ethical impact on the students, although there is a certain difference in their presence and representation in different departments. 


\section{Literature:}

АНГЕЛОСКА-ГАЛЕВСКА, Наташа (1998). Квалитативни истражувань во воспитанието и образованието. Битола: Киро Дандаро.

БЕРЕЛСОН, Бернард (1995). „Анализа садржаја”, Пејчић, Б. (ур.), Методологија емпиријског научног истраживаньа. Београд: Дефектолошки факултет.

ГРЕДЕЉ, Стјепан (1986). С ону страну огледала. Београд: Истраживачко издавачки центар ССО Србије.

JAHЕВСКА, Маја (2021). Користенье на литературните дела во наставата по Македонски јазик. Скопје: Филозофски факултет.

НАСТАВНА ПРОГРАМА ПО МАКЕДОНСКИ ЈАЗИК ЗА І ОДДЕДЕНИЕ ВО ДЕВЕТГОДИШНОТО ОСНОВНО ОБРАЗОВАНИЕ. (2007). Скопје: Биро за развој на образованието.

НАСТАВНА ПРОГРАМА ПО МАКЕДОНСКИ ЈАЗИК ЗА ІІ ОДДЕДЕНИЕ ВО ДЕВЕТГОДИШНОТО ОСНОВНО ОБРАЗОВАНИЕ. (2007). Скопје: Биро за развој на образованието.

НАСТАВНА ПРОГРАМА ПО МАКЕДОНСКИ ЈАЗИК ЗА ІІІ ОДДЕДЕНИЕ ВО ДЕВЕТГОДИШНОТО ОСНОВНО ОБРАЗОВАНИЕ. (2007). Скопје: Биро за развој на образованието.

НАСТАВНА ПРОГРАМА ПО МАКЕДОНСКИ ЈАЗИК ЗА ІV ОДДЕДЕНИЕ ВО ДЕВЕТГОДИШНОТО ОСНОВНО ОБРАЗОВАНИЕ. (2007). Скопје: Биро за развој на образованието.

НАСТАВНА ПРОГРАМА ПО МАКЕДОНСКИ ЈАЗИК ЗА V ОДДЕДЕНИЕ ВО ДЕВЕТГОДИШНОТО ОСНОВНО ОБРАЗОВАНИЕ. (2007). Скопје: Биро за развој на образованието.

НАСТАВНА ПРОГРАМА ПО МАКЕДОНСКИ ЈАЗИК ЗА VІ ОДДЕДЕНИЕ ВО ДЕВЕТГОДИШНОТО ОСНОВНО ОБРАЗОВАНИЕ. (2007). Скопје: Биро за развој на образованието.

BERELSON, Bernard (1952). Content Analysis in Communication Research. New York: Free Press.

BUSHA, Charles H. \& HARTER, Stephen P. (1980). Research Methods in Librarianship: Techniques and Interpretation. New York: Academic Press.

DE SOLA POOL, Ithiel. (1959). Trends in Content Analysis. Urbana: University of Illinois Press, 1959.

KRIPPENDORFF, Klaus. (1980). Content Analysis: An Introduction to its Methodology. Beverly Hills: Sage Publications. 
